\title{
Me dá um dinheiro aí!: \\ estudo sobre as relações e intersecções entre publicidade e criatividade para a sustentabilidade carnavalesca interiorana
}

\author{
Give me some money!: \\ study on the relationships and intersections between advertising and \\ creativity for non-central cities carnival sustainability
}

\author{
¿Dame algo de dinero!: \\ estúdio sobre las relaciones e intersecciones entre publicidade y \\ creatividad para la sostenibilidad del carnaval interior
}

\author{
Eduardo Moura \\ Universidade Federal de Santa Maria - RS - Brasil \\ ORCID: https://orcid.org/0000-0003-4317-2841 \\ Endereço currículo Plataforma Lattes: http://lattes.cnpq.br/0555689337141027 \\ E-mail: eduardommoura@yahoo.com.br \\ Janderle Rabaiolli \\ Universidade Federal de Santa Maria - RS - Brasil \\ ORCID: https://orcid.org/0000-0003-0885-9189 \\ Endereço currículo Plataforma Lattes: http://lattes.cnpq.br/1863748565410985 \\ E-mail: janderle.rabaiolli@ufsm.br
}

\begin{abstract}
Resumo: Este artigo busca apresentar relações e intersecções entre três objetos principais: Carnaval, Publicidade e Indústria Criativa, com o intuito de encontrar e propor soluções para o desenvolvimento e a rentabilidade do festejo em cidades nãocentrais - associadas, sobretudo, à perspectiva do município de Rio Pardo (Rio Grande do Sul) -, que conjunturalmente possuem menos recursos e interesse público e privado para a sua execução. Para isso, demonstra-se a valorização da Indústria Criativa, a criatividade e o conhecimento da publicidade em hibridização como soluções para a sustentabilidade carnavalesca. A materialização deste trabalho consiste na construção de um referencial teórico, fundamentados em obras como o "Mapeamento da Indústria Criativa no Brasil" (FIRJAN, 2017), "Publicidade Híbrida" (COVALESKI, 2010) e "Cadeia Produtiva da Economia do Carnaval" (PRESTES FILHO, 2012).
\end{abstract}

Palavras-chave: Carnaval interiorano. Publicidade híbrida. Indústria criativa. Produção cultural. Entretenimento. 


\begin{abstract}
This article seeks to present relationships and intersections between three main objects: Carnival, Advertising and Creative Industry, with the aim of finding and proposing solutions for the development and profitability of the celebration in noncentral cities - associated, above all, with the perspective of the city of Rio Pardo (Rio Grande do Sul, Brazil) -, which contextually have fewer resources and public and private interest for their execution. Therefore, the text exposes the appreciation of the Creative Industry, creativity, and knowledge of hybridization advertising as solutions for carnival sustainability. The materialization of this work consists in the construction of a theoretical framework, based on works such as the "Mapping of the Creative Industry in Brazil" (FIRJAN, 2017), "Hybrid Advertising" (COVALESKI, 2010), and "Carnival Economy Productive Chain" (PRESTES FILHO, 2012).
\end{abstract}

Keywords: Non-central cities carnaval. Hybrid advertising. Creative industry. Cultural production. Entertainment.

Resumen: Este artículo busca presentar relaciones e intersecciones entre tres objetos principales: Carnaval, Publicidad e Industria Creativa, con el objetivo de encontrar y proponer soluciones para el desarrollo y la rentabilidad de la celebración en ciudades no centrales - asociadas, sobre todo, a la perspectiva de la ciudad de Rio Pardo (Rio Grande do Sul, Brasil) -, que contextualmente tienen menos recursos e interés público y privado para su ejecución. Por tanto, el texto expone la valoración de la Industria Creativa, la creatividad y el conocimiento de la publicidad de hibridación como soluciones para la sostenibilidad del carnaval. La materialización de este trabajo consiste en la construcción de un marco teórico, basado en trabajos como el "Mapeo de la Industria Creativa en Brasil" (FIRJAN, 2017), "Publicidad Híbrida" (COVALESKI, 2010), y "Cadena Productiva de la Economía del Carnaval"(PRESTES FILHO, 2012).

Palabras clave: Carnaval de ciudades no centrales. Publicidad híbrida. Industria creativa. Producción cultural. Entretenimiento.

\title{
1. Indústria criativa e a criação de oportunidades comerciais
}

Na década de 1960, as estruturas teóricas das indústrias culturais se apoiavam em uma sociedade afluente. Acreditava-se que as pessoas passariam a buscar bens e serviços embutidos no lazer, entretenimento e bens culturais para se satisfazerem e, progressivamente, passariam a fazer parte dos padrões de consumo (BENDASSOLLI et al, 2009). Essas tendências se concretizaram nas décadas seguintes e os hábitos de consumo em massa se tornaram cada vez mais segmentados. Na década que encerrou o milênio, porém, o capital cultural (os ativos sociais de um indivíduo, como educação, intelecto, vestuário etc.), aliado ao capital econômico, passou a ser ainda mais 
valorizado nos padrões de consumo. Uma nova classe de serviços surge, por conseguinte, como a "economia da cultura", com atividades que têm origem na criatividade, nos talentos e nas habilidades individuais.

A nomenclatura "indústrias criativas", como conhecemos hoje, portanto, se associa com as mudanças socioeconômicas ocorridas em países industrializados na última década do século XX, com a locomoção do foco das atividades industriais para acentuadas ações em torno do conhecimento, principalmente no setor de serviços. O conceito é australiano, mas foi em terras inglesas que ganhou maior impulso, principalmente com a associação do tema com o âmbito político. Sendo este o primeiro país que classificou e detalhou as atividades dessa indústria, a classificação contou com itens como:

publicidade, arquitetura, mercado de artes e antiguidades, artesanato, design, design de moda, cinema, software, softwares interativos para lazer, música, artes performáticas, indústria editorial, rádio, TV, museus, galerias e as atividades relacionadas às tradições culturais. (DCMS apud BENDASSOLLI et al, 2009, p. 2).

Entre os componentes principais das Indústrias Criativas, a criatividade é o elemento central e necessário para a geração de propriedade intelectual, definida também como a expressão do potencial humano de realização, manifestado na geração de produtos tangíveis a partir da manipulação de objetos do mundo externo para a concretização de suas fantasias e desejos. A cultura tratada na forma de objetos culturais (onde seu valor é atribuído e sua utilidade é percebida), é o fator que o contribui para a decisão no ato do consumo: as percepções culturais ultrapassam as propriedades físicas ou materiais de um produto. A propriedade intelectual é significada a partir do valor econômico atribuído na disseminação dos produtos criativos. Por último, a convergência entre artes, negócios e tecnologias, fenômeno milenar institucionalizado nos empreendimentos humanos desde por meio da criatividade, variando periodicamente em termos de estrutura (BENDASSOLLI et al, 2009).

No que tange à atualidade, o uso intensivo de tecnologias de informação e de comunicação permite a descentralização de atividades concentradas nas grandes organizações para pequenas empresas e comunidades, que finalmente podem se apropriar das manifestações culturais e disseminar suas criações com mais liberdade e facilidade. 


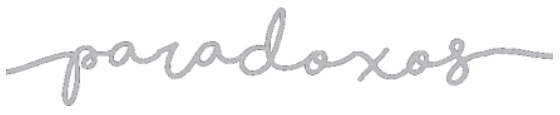

Me dá um dinheiro aí!:

Estudo sobre as relações e Intersecções entre publicidade e Criatividade para a sustentabilidade Carnanvalesca interiorana

MOURA, RABAIOLLI, 2021

No Brasil, ações para desenvolver a economia criativa tiveram força em 2011, quando o Ministério da Cultura lançou o Plano da Secretaria da Economia Criativa, visando definir políticas e diretrizes para promovê-las. O Decreto 7.743 de 2012 regulamentou a criação da Secretaria da Economia Criativa, órgão que foi desarticulado pelo Governo Federal três anos depois, evidenciando a incompreensão da temática e de sua importância estratégica para o país, entre fatores como a divergência de interesses políticos e a falta de conhecimento sobre o setor cultural.

Desde 2014, segundo dados da FIRJAN (2019), a participação criativa vem se estabilizando no Brasil, girando em torno de 2,62\% de toda a riqueza gerada em território nacional, até 2019. Em 2017, foram contabilizados 245 mil estabelecimentos, cujas ideias são os principais insumos de produção. Portanto, apesar da sua valorização tardia, o mercado de trabalho criativo vem se alinhando ao restante da economia brasileira. No Rio Grande do Sul, em 2019, o número de microempreendedores individuais (MEIs) criativos ultrapassou 48 mil (FIRJAN, 2019), marca expressiva para um estado culturalmente conservador no viés empresarial. Deve-se considerar, também, que grande parte das atividades econômica criativas informais não costumam ser atestadas pelas agências de pesquisas responsáveis por essas estatísticas, o que não permite ter a exata dimensão da importância do setor que, justamente, se caracteriza pela alta informalidade.

A Economia Criativa, considerada apenas um nicho há pouco tempo, tornou-se, ao lado da inovação, um elemento tão relevante quanto o capital para o mercado e para o desenvolvimento do país. O efeito se multiplica com a quantidade crescente de setores (públicos, privados, terceiro setor, instituições de ensino etc.) que buscam aprimorar seus processos, produtos e serviços; ampliar seus alcances e caminhos; e promover a eficiência estratégica. Além de possuir um caráter multidisciplinar, também é transversal, tanto entre os setores criativos, quanto com a participação de outros setores. No país, por exemplo, 181,5 mil dos 837,2 mil indivíduos mapeados pela FIRJAN (2019), atuavam na Indústria Clássica (Indústria de Transformação).

Dessa forma, agrega-se valor ao ativo intelectual e ao objetivo econômico. Para facilitar a compreensão da atuação da Indústria Criativa, a Federação das Indústrias do Estado do Rio de Janeiro a divide em treze classificações, agrupadas em quatro grandes áreas de acordo com suas afinidades. Dentro da seção "Cultura", o Carnaval é potência na geração DOI: http://doi.org/10.14393/par-v6n2-2021-63260 - Paradoxos, Uberlândia, v. 6, n. 2, p. 243-272, jul./dez. 2021 | 246 
de demandas para diferentes setores econômicos. Os empregos vinculados à Publicidade \& Marketing não estão concentrados apenas em meios estritamente comunicativos, como agências de publicidade, produtoras audiovisuais e editoras; empresas de diversas áreas mercadológicas vêm buscando esse meio objetivando melhores resultados, diferenciação em seus produtos e novas aplicações, públicos e linguagens, dentro do contexto mundial de transformação digital e da valorização da experiência do consumidor.

\section{Publicidade, carnaval e criatividade}

A criatividade e a imaginação são algumas das moedas principais na materialização de produtos, fontes produtivas essenciais para a elaboração de elementos surpreendentes também no Carnaval e isso se converte em oportunidades, negócios e demandas para outros setores econômicos. A intangibilidade da experiência e a geração de valor são valores fundamentais para a sustentabilidade de qualquer empreendimento, isso é, a capacidade de sustentar projetos a longo prazo, consistindo na estabilidade de parâmetros ambientais, econômicos ou sociais. Nesse quesito, a busca pela originalidade e pelo conhecimento do consumidor pressupõe a valorização de um setor em que a expressão criativa é comumente atrelada como um sinônimo: propaganda.

As classificações referentes à Indústria Criativa listam atividades comunicacionais, identificando-as, portanto, ora como um segmento e ora como auxiliadoras de atividades que necessitam de contribuição comunicacional e, nesse caso, a comunicação presta assistência à Indústria Criativa. Em classificações realizada pela Conferência das Nações Unidas sobre Comércio e Desenvolvimento - UNCTAD (2012), a comunicação está localizada nos grupos "Mídia", "Criações funcionais" e "Serviços criativos" (publicidade e outros serviços criativos digitais) (FEIL; GUINDANA et, al, 2018). Já na classificação da FIRJAN (2019), a comunicação se posiciona na primeira área criativa, "Consumo" - a principal em termos de trabalhadores formalmente empregados (43,8\% dos vínculos formais em 2017) -, "Mídias" e “Audiovisual”.

Com a análise das referências bibliográficas, podemos considerar o carnaval como um dos produtos que recebem o auxílio da comunicação para a ampliação de seu alcance. 
Nesse sentido, vemos as expressões culturais e produções culturais como parte da área criativa "Cultura" (FIRJAN, 2019). O setor cultural também envolve outras áreas dentro da Economia Criativa (como a publicidade, a moda e a editoração), em que artistas musicais, plásticos, artesãos e compositores, por exemplo, cumprem papéis importantes.

O ecossistema citado auxilia para que o Brasil seja visto como uma experiência e um produto cultural e criativo, combinando a diversidade social e nossas referências ancestrais para imprimir identidade na música, no cinema, na moda e no esporte, sintetizando algumas das produções criativas memorizadas no imaginário global. Ademais, o Carnaval, com estrutura distinta em cada canto do país, possui programação que contribui para prover conteúdo aos turistas e públicos gigantescos e oportunidades em diversos setores formais e informais, dentro e fora da Indústria Criativa, como o turismo.

Mesmo assim, a valorização da criatividade e o incentivo às estratégias criativas ainda é pouco percebido, principalmente quando evidencia-se seus papéis fundamentais na disseminação da imagem brasileira para todas as orientações do planeta. Em nível regional, por exemplo, não há uma unidade quanto às suas aplicações em celebrações carnavalescas do interior do Brasil, refletida na baixa percepção de seus potenciais pelos atores envolvidos.

O Brasil tem como oportunidade, para a produção artística e cultural, a Lei de Incentivo à Cultura, que busca fomentar projetos de incentivo à formação de elementos como a difusão do patrimônio (artístico, cultural e histórico) e o estímulo ao conhecimento cultural. Segundo a Secretaria Especial da Cultura ${ }^{1}$, qualquer pessoa física ou jurídica pode financiar os projetos, direcionando-os $6 \%$ ou $4 \%$, respectivamente do imposto devido ao governo.

Ainda, a publicidade pode auxiliar na pedagogia das instituições carnavalescas quanto aos interesses comercial e marcário, e esse mecenato transcende os aspectos econômicos e encontra aspectos de capacitação e suporte técnico para a exploração dos potenciais do evento pelos atores e, consequentemente, para a sua autonomia em relação ao setor público.

\footnotetext{
${ }^{1}$ Para mais informações, ver: SECRETARIA ESPECIAL DA CULTURA. Como Funciona - Lei de Incentivo à Cultura. Cultura.gov.br. Disponível em: http://leideincentivoacultura.cultura.gov.br/comofunciona. Acesso em: 7 fev. 2021. 


\section{Publicidade híbrida: um meio não-intrusivo}

Desde os anos 90, a realidade da propaganda e do marketing passou por grandes transformações e redirecionamentos, oriundas da segmentação dos mercados e a ampliação dos canais de comunicação. Mesmo que o desenvolvimento exponencial do virtual tenha embargado a propaganda massiva e, consequentemente, diminuído as verbas das agências na época, também trouxe transformações que contribuíram para a precisão dos serviços oferecidos, como a focalização de mercados específicos com o uso de mídias específicas.

Como consequência do desenvolvimento da sociedade, existe uma espécie de senso comum em que a publicidade e a propaganda são reflexos sociais. Portanto, conforme as relações e o sistema se transformam, o setor também se modifica e elenca novas demandas. Em paralelo aos avanços, a propaganda perde o destaque entre as ferramentas de comunicação, dando espaço para novas configurações e modelos de negócios em publicidade, que são fluídos e constantemente se transformam, fruto do surgimento de um público consumidor com grande poder de decisão e dentro de uma ampla variedade de canais, usufruindo dos mecanismos de reação contemporâneos.

A ideia de ter a publicidade como meio de persuadir e anunciar para um público massivo se encontra cada vez mais obsoleta - mesmo que esteja longe de se tornar inexistente - com o desenvolvimento da tecnologia e possibilidade de uma interação entre emissor e receptor. Nesse contexto, a segmentação de nichos é o caminho a ser seguido, com maior valorização da opinião e exigências do consumidor, como maneira de atuar diante da crescente diversidade e oferta maiores, dentro da competitividade mercadológica mundial.

Também passa a ser necessário, para a sustentabilidade do setor, ver a publicidade dentro de um composto comunicacional, em conjunto com atividades promocionais e o aproveitamento e recrutamento de expertises. Para o bom alinhamento entre as instituições e os consumidores, conhecimentos em Inteligência Artificial, armazenamento e conversão de dados em conhecimento, por meio das mudanças socioculturais causadas pelos avanços digitais, em um mercado cada vez mais marcado pela interação e pelo compartilhamento.

Nessa conjuntura, um pensamento crítico acerca da publicidade se estabelece, com um paradigma a ser seguido para a compreensão dos fenômenos de "sincretização de 
linguagens e hibridização de culturas" (COVALESKI, 2010, p. 34). Proposto por Rogério Covaleski na obra "Publicidade híbrida", o conceito de mesmo nome consiste no "processo de hibridização da publicidade a partir do diálogo e das intersecções cada vez mais intensas entre três atores do ambiente midiático contemporâneo: o mercado publicitário, a indústria do entretenimento e as tecnologias interativas" (COVALESKI, 2010, p. 12). O hibridismo, como linguagem resultante da mistura dos vocabulários ou da interpretação de sintaxes de línguas distintas, potencializa a publicidade como "mistura", aderindo e interpenetrando novos meios e maneiras para atender às novas demandas do mercado e ir além da função básica de informar, assumindo novos formatos.

Sobre essas reconfigurações, a mensagem atrai o público de uma maneira interativa e afetiva, por meio da elaboração de peças, ações e campanhas que abrem espaço para o entretenimento e interatividade, criando uma experiência única de imersão. Contribuindo para a correlação da marca à ideia criativa, a comunicação por conteúdo ou branded contente é um exemplo que se cristaliza nessa nova cultura de consumo, dando origem a um universo criativo para desenvolvimento de imagem de marcas ao utilizar a atração "entretível" (neologismo utilizado por Rogério Covaleski para designar qualidades relativas a entretenimento), para a integração do discurso. Sem causar empecilhos ao consumo intencional, trata-se de "uma cocriação convergente em prol da trindade do marketing: conteúdo, mídia e marcas” (COVALESKI, 2010, p. 53).

Nesse sentido, ao mesmo tempo que o anunciante é favorecido, recuperando certo poder impositivo sobre sua propriedade marcaria, aumenta-se, também, a chance desses conteúdos serem mais bem disseminados nas mídias a partir da reação do receptor à mensagem embutida, a partir de seus sentidos, sensibilidade, raciocínio e perspicácia. A horizontalidade dos hábitos de consumo contribui à confiança no serviço ou produto entre os usuários, que compartilham suas percepções e experiências, retirando o papel de emissor privilegiado da marca. Com senso crítico aguçado pela autonomia, a possibilidade de expandir a experiência dos consumidores, por meio da emoção, criatividade, entretenimento e diversão, deixa de ser uma cogitação e passa a ser necessidade.

Esse tipo de comunicação ocasiona uma transformação no produto midiático em entretenimento publicitário interativo, ao mesmo tempo que é hibridizada por quatro dimensões: a persuasão, que sempre orientou os esforços criativos devido ao convencimento DOI: http://doi.org/10.14393/par-v6n2-2021-63260 - Paradoxos, Uberlândia, v. 6, n. 2, p. 243-272, jul./dez. 2021 | 250 
do receptor em relação ao conteúdo; o entretenimento em si, por meio da fruição da estética e distração intelectual pela mensagem, conforme citado anteriormente; a interação, responsável por mediação do conteúdo; e o compartilhamento, ou seja, recomendação espontânea realizada pelo receptor (COVALESKI, 2010).

O primeiro elemento é considerado um elemento essencial do discurso publicitário, que sempre orientou os esforços criativos devido ao convencimento do receptor em relação ao conteúdo, levando-os à compra. Passa-se a atribuir a sutileza entre suas características, tendo como exemplos, na publicidade brasileira, a sedução, o humor, a ludicidade e suas misturas como os apelos de maior eficácia (COVALESKI, 2010). Em discurso ou ação publicitárias dotadas de persuasão "se deve estabelecer uma relação de empatia - minimamente - entre o emissor e o receptor da mensagem, seja pelo impacto que cause à primeira vista ou pelo uso de símbolos comuns ao imaginário deste indivíduo". (COVALESKI, 2010, p. 66).

Entre os elementos constituintes da hibridização, a busca da interação se demonstra fundamental para a propaganda - principalmente em cenário tecnológico e inovativo como o atual -, em todos os seus meios e campos de atuação. Compreende-se como "uma forma de comunicação mediada que possibilita, a partir de mecanismos de ação entre emissores e receptores, a interferência em conteúdos disponibilizados em plataformas comunicacionais suscetíveis a estas ações" (COVALESKI, 2010, p. 81).

Todo o investimento em interação, seja em mídias alternativas ou em marketing digital, é realizado com a expectativa da geração de compartilhamento, outra atribuição de um produto híbrido, por meio do estímulo à proliferação viral e exponencial e do incentivo ao consumo. Compartilhar, nesse sentido, é compreendido como uma “intenção espontânea do receptor em partilhar conteúdos sorvidos a partir de uma experiência positiva empreendida" (COVALESKI, 2010, p. 88).

A publicidade, mesmo cumprindo seu papel mercadológico, retira o foco da mensagem sobre o consumo de anúncios publicitários, enfatizando a experiência da ação ou a estética da peça. Alia-se ao entretenimento (como formato, discurso e indústria) para a produção midiática em ambiente e época favoráveis ao compartilhamento (distribuição espontânea das mensagens pelo público, sobretudo mediadas por prosumers, o consumidor que se envolve ativamente na criação de novos produtos ou em criar informações e DOI: http://doi.org/10.14393/par-v6n2-2021-63260 - Paradoxos, Uberlândia, v. 6, n. 2, p. 243-272, jul./dez. 2021 | 251 
conteúdos). O entretenimento publicitário, materializado em conteúdos híbridos, busca capturar a atenção de consumidores e produtores de influência por meio da interação e da experiência, utilizando-se de recursos persuasivos a fim de responder às suas exigências e atribuir sentido às suas ações de consumo.

\section{Carnaval: inovações no âmbito criativo e cultural}

Assim como a propaganda, a evolução da utilização do carnaval como plataforma midiática ocorre quando se deixa de focar nos produtos a serem vendidos, para comunicar comportamentos e valores, correlacionando símbolos de diversão, alegria e confraternização de ambas as partes em soluções híbridas.

Para gerar entretenimento e produzir conteúdo relevante ao consumidor, a experiência se sobressai ao produto e a diversidade de canais disponíveis na plataforma é visto como ponto positivo para a disseminação de mensagens que, no contexto atual, passam a ser consequências de demandas dos consumidores. Além disso, a sazonalidade permite que as campanhas possuam um prazo definido de veiculação e, assim, as chances de uma campanha fracassar e causar prejuízos são reduzidas, devido à rápida retirada das mídias.

A observação das atividades econômicas que envolvem a materialização dos produtos carnavalescos tem como principais valores a criatividade e a imaginação e, diante da magnitude do Carnaval como fenômeno comunicativo, social e antropológico, é improvável não associar marcas ao evento. É uma plataforma que a publicidade busca para não ser intrusiva e que tem todo o consumismo que a abrange, legitimado por ela, que atrai e envolve o público para o espetáculo, seja um desfile ou quaisquer comemorações carnavalescas.

Como produto midiático, a festividade é destinada a sorver de ludicidade os momentos de contemplação dos indivíduos, um paradigma da ilusão a ser consumido na televisão, no meio virtual e nas ruas, sendo, talvez, "em um mundo cada dia mais áspero e sério [...] a única festa permitida, a festa das massas, tão cheia de ilusão como de frustração, tão programada e artificial como todo o resto da vida consumida" 
(MARTÍN-BARBERO apud LUDERER, 2007, p. 42). Assemelha-se, portanto, à fruição estética e a distração intelectual da publicidade em hibridização, sendo uma das mais importantes movimentações da indústria do lazer e do conteúdo e, igualmente, contribuindo para a formação do repertório cultural e social dos indivíduos, além de ser um potente gerador de demandas para outros setores econômicos, gerando receita e oportunidades, inclusive, para a Indústria Criativa a qual está inserida.

Em cidades interioranas, a publicidade não é tão utilizada para favorecer a amplitude e o alcance da festividade, em comparação às capitais e cidades turísticas, onde está correlacionada ao evento, devido à conexão entre sua grandiosidade e a midiatização desenvolvida durante décadas, assim como o elo construído entre marcas e órgãos organizadores.

Apontadas as inovações no âmbito criativo e cultural para o desenvolvimento da indústria carnavalesca no Brasil, passa-se a compreender como as quatro dimensões da publicidade em hibridização podem ser utilizadas para o impulsionamento do carnaval, sobretudo, o rio-pardense, favorecendo aderência, pertinência e adequação do pronunciamento de marcas e ressaltando a importância da sazonalidade para os agentes envolvidos no evento e de sua importância para a região em que está inserido.

Lembremos, neste sentido, a utilização da plataforma para a realização de ações e a fruição de possibilidades, principalmente pela conveniência de se fugir da inserção estandardizada da Comunicação em um ambiente, efetivamente, sem uma estrutura completa de sobriedade e austeridade, por se tratar de um formato absolutamente dinâmico e passível de estratégias alternativas.

Pela similaridade de características da festividade e por se tratar de uma das maiores ocasiões de consumo, marcas do segmento de cerveja tendem a patrocinar grandes eventos carnavalescos ao redor de todo o Brasil. Apesar de se tratar de um período especial, os anunciantes ainda devem estar comprometidos com a ética na propaganda comercial veiculada.

Para apontarmos a publicidade no carnaval, objeto deste trabalho, como híbrida, dependemos de materialidades. Em paralelo ao estudo da festividade como plataforma midiática, de maneira ampla, também se faz necessário contextualizar, novamente, os quatro elementos constituintes do conceito híbrido: persuasão, entretenimento, interação e compartilhamento. 
O carnaval é um período de engajamento multimídia do público, tratando-se de uma plataforma em que o marketing é aplicado em estratégias físicas, com altos investimentos em meios alternativos. Também é diretamente conectada com as redes sociais e a mídia paga, para divulgação massiva e de maior amplitude. Em ambos os casos, há a expectativa de persuasão e da geração de compartilhamento de imagens, vídeos e histórias, por meio do estímulo à proliferação viral e exponencial e do incentivo ao consumo.

Persuadir, nesse sentido, envolve o uso da linguagem manipuladora clássica da publicidade, por meio da tentação e da sedução, por exemplo. É uma prática comum do discurso publicitário, que procura ressaltar ou prevalecer aspectos positivos de um produto ou serviço sobre os negativos, evitando formas de ordem negativas que envolvem intimidação ou provocação. No lugar, busca-se demonstrar as competências, vantagens ou capacidades que o consumidor pode adquirir ao fazer uso do produto anunciado. Também é comum apontar a condição de mudança comportamental ou de conduta. (COVALESKI, 2010). Compartilhar é compreendido como uma "intenção espontânea do receptor em partilhar conteúdos sorvidos a partir de uma experiência positiva empreendida" (COVALESKI, 2010, p. 88).

Correspondendo ao primeiro dos requisitos propostos para ser definir a plataforma cultural carnavalesca como híbrida (independente de recortes específicos, conceituando-se de maneira ampla a festividade e as possibilidades de sua utilização), a persuasão, é possível afirmar que se faz plausível e exequível a veiculação de uma propaganda criativa, alternativa e até mesmo tradicional, para fins persuasivos em diversos níveis e meios.

Há, conforme os objetivos do anunciante, o convencimento de se fazer algo que a mensagem coloca para que o público aja e reaja, especialmente por se tratar de uma sazonalidade festiva e uma oportunidade comercial ou de promoção de mensagens sociais para o meio comunicativo. De fato, o entretenimento é aplicado à publicidade, neste âmbito, ao se retirar o foco da mensagem sobre o consumo de anúncios, enfatizando a atenção pela experiência ou a sensibilidade pela estética, com um aparente embelezamento do cotidiano em um trecho específico do ano, em que muitos dos problemas políticos e sociais passam a ter menor importância.

Por isso, a intersecção que ocorre entre informação, entretenimento e propaganda é direcionada e recebida de maneira menos intrusiva - em comparação a outras oportunidades DOI: http://doi.org/10.14393/par-v6n2-2021-63260 - Paradoxos, Uberlândia, v. 6, n. 2, p. 243-272, jul./dez. 2021 | 254 
e datas em que a influência publicitária é problematizada. Dessa forma, abrem-se novos caminhos para a criatividade e a inovação, tornando a interação, além de um resultado desejado, algo possível com o engajamento das multidões.

Por fim, sob a perspectiva de um fenômeno do compartilhamento da propaganda neste objeto, trata-se de um momento oportuno para as marcas que almejam a aproximação dos públicos. O ambiente digital, principalmente, é o meio em que as pessoas estão mais presentes e atuantes e, nessa conjuntura, compartilhar imagens, vídeos, histórias e interagir com os amigos são práticas comuns entre os brasileiros.

\section{Carnaval como fenômeno comunicativo}

Em meados do século XIX, na cidade do Rio de Janeiro, o carnaval passava a se estruturar como a principal festa nacional e popular, principalmente com o surgimento de cordões e blocos, servindo como referência para demais cidades brasileiras. Na década de 70, algumas das instituições tradicionais se transformaram e influenciaram a criação de escolas de samba, que contribuíram para a organização carnavalesca e o crescimento dos desfiles. (DA MATTA apud TURETA; DE ARAÚJO, 2013).

Atualmente, entre as diversas formas de celebrá-lo, se destaca as escolas de samba e blocos nas avenidas do país. A festa popular, espontaneamente, é um fenômeno comunicativo e cheio de criatividade, por suas fantasias majestosas e abadás que caracterizam grupos de pessoas entre as multidões, percussões e baterias que fazem parte dos enredos modificados anualmente, símbolos regionais e ritmos variados, que vão muito além do samba. Essa diversidade, multiplicada pela mídia, "atinge as mais diversas faixas de renda e idade" e, por isso "o Carnaval é uma oportunidade para marcas comunicarem seu propósito e seus produtos e serviços aos consumidores em um momento de descontração e alegria" (STRANO, 2019).

O Carnaval, produto já consumido por milhares de pessoas, passou a ser transmitido para milhões de pessoas do país e do mundo por meio da televisão e da internet. Se no início da festividade as relações eram de voluntariado e alinhadas unicamente ao lazer dos envolvidos, a partir da entrada do dinheiro do Estado e do financiamento dos meios de comunicação, como a televisão, do turismo e da inclusão das classes médias nos 
sambódromos, essas relações tomam-se profissionais, havendo a necessidade de se contratar outros profissionais especializados (BLASS apud BARONETTI, 2014, p. 140). Prestes Filho (2012, p. 5) traz o conceito de "cadeia produtiva", que consiste no conjunto sequenciado de atividades que culminam em entretenimento, desfiles, interesses publicitários e todo o entusiasmo do público pelas festividades carnavalescas, na espera pelos enredos, fantasias e carros alegóricos, por exemplo.

A distribuição dos produtos carnavalescos fica por conta dos agentes de divulgação, seleção do samba, marketing e da Publicidade. A comercialização é feita no sambódromo, nas quadras, TVs, rádios, jornais, revistas, folhetos e internet. Finalmente, o consumo do desfile, por exemplo, já é feito na avenida e em pavilhões desde os ensaios e, durante a festa, também em camarotes. O carnaval também é exportado e vendido como produto cultural (DVD, CD, cinema, livro e vídeo, por exemplo). (PRESTES FILHO, 2012).

Indiretamente, indústrias editoriais e gráficas (revistas, folhetos, jornais e livros), audiovisuais (TV, DVD, cinema e rádios), de Internet (sites culturais, informativos e comerciais), fonográfica (CD e pirataria), fazem parte da economia do carnaval, usufruindo da festividade para a criação e disseminação de produtos. (PRESTES FILHO, 2012).

Deve-se destacar, também, a importância dos blocos e bandas, instituições carnavalescas que trazem o espírito de festa de forma descontraída, se opondo aos processos profissionalizados e altamente organizados das grandes escolas de samba, mas que também possuem interesses comerciais, como contratos com músicos, grupos, carros de som, ambulantes, produção de eventos derivados, como feijoadas e rodas de samba, a criação de abadás temáticos e, em alguns casos, fantasias e adereços.

É possível admitir, tendo como espelho a década de 80 para o Carnaval de São Paulo, que a publicidade foi essencial para o crescimento do Carnaval em todo o país. Além de servir de fonte de receita, as cotas de publicidade disponibilizadas nos espaços das avenidas causaram uma transformação na estrutura da festividade, proporcionando a criação e a ampliação de oportunidades para a contratação de profissionais que auxiliaram na consagração do evento no país e sua atual grandiosidade. Com novas possibilidades de execução, vê-se, também, uma valorização da criatividade como um importante fator para o desenvolvimento e a aplicação de inovações no evento. 
Em 1973, foram criadas duas diferentes federações carnavalescas, a Associação das Escolas de Samba de São Paulo (AESSP) e a União das Escolas de Samba Paulistanas (UESP), fundada por sambistas, radialistas e atraindo intelectuais e profissionais de comunicação, buscando maior legitimidade e atenção por parte do poder público (BARONETTI, 2014). Nos primórdios da relação publicidade-carnaval, em 1985, a extinta TV Manchete propôs um contrato de exclusividade para a transmissão dos desfiles das Escolas de Samba do Grupo I paulista, em troca do pagamento dos direitos de imagem, repassados diretamente às escolas de samba pela UESP. No ano seguinte, a Rede investiu 8 bilhões de cruzeiros para exibir o carnaval carioca e das principais cidades do país, mobilizando 870 profissionais. Com a venda de oito cotas de patrocínio, nacionais e locais, faturou C\$ 15 bilhões, resultado de um negócio rentável e com alto potencial de crescimento.

Em 1987, com a organização do evento sob a responsabilidade da Liga, empresários se interessaram em comprar cotas de publicidade maiores da Avenida Tiradentes, oportunidade para divulgarem suas marcas para as 25 mil pessoas presentes no evento, além dos milhares de telespectadores da Rede Manchete. Posteriormente, os três principais canais de financiamento das escolas paulistas tornaram-se: 1) as verbas oficiais da prefeitura; 2) as verbas de direitos de transmissão dos veículos; e 3 ) o repasse de uma parte do total arrecadado com a venda de ingressos (BARONETTI, 2014). Assim, as estruturas tornaram-se maiores, mais resistentes e mais luxuosas.

A Comunicação pode contribuir para a valorização ou a ignorância do público no tocante do Carnaval. Apesar de ser considerada a maior celebração brasileira, muitas pessoas não se identificam com o evento e sua carga simbólica. Ademais, em grande parcela dos municípios brasileiros não se comemora a data, tratando-se apenas de mais um feriado anual. Cabe, então, às prefeituras e secretarias das cidades em que a cerimônia é ocorrida, inovar e manter o interesse público acerca de sua importância algo que desinteressa muitos desses órgãos e aparenta ter maior incentivo público e privado apenas em capitais estaduais. 


\section{Celebração em cidade interiorana:}

Para a compreensão das características e apreensão de um possível padrão entre as festividades carnavalescas interioranas, realizou-se uma pesquisa exploratória, de caráter qualitativo, com a realização de um estudo de caso - metodologia que "considera as características holísticas e significativas dos eventos da vida real" (YIN, 2015, p.2) analisando eventos de todas as regiões do Brasil.

A seleção das cidades foi realizada de maneira informal pela ferramenta Stories do aplicativo Instagram, que torna possível a publicação de coleções curtas de fotos e vídeos por usuários. Optou-se pelo compartilhamento de um card (Figura 1), acrescido de uma enquete que incitava a prospecção por comemorações em nível nacional. Essa atividade foi realizada em comunhão com amigos e conhecidos, preferencialmente naturais de outros estados do país. Os resultados da pesquisa se encontram na nuvem de palavras da Figura 2.

Figura 1 - Enquete sobre celebrações interioranas, enviada pelo Instagram Stories.

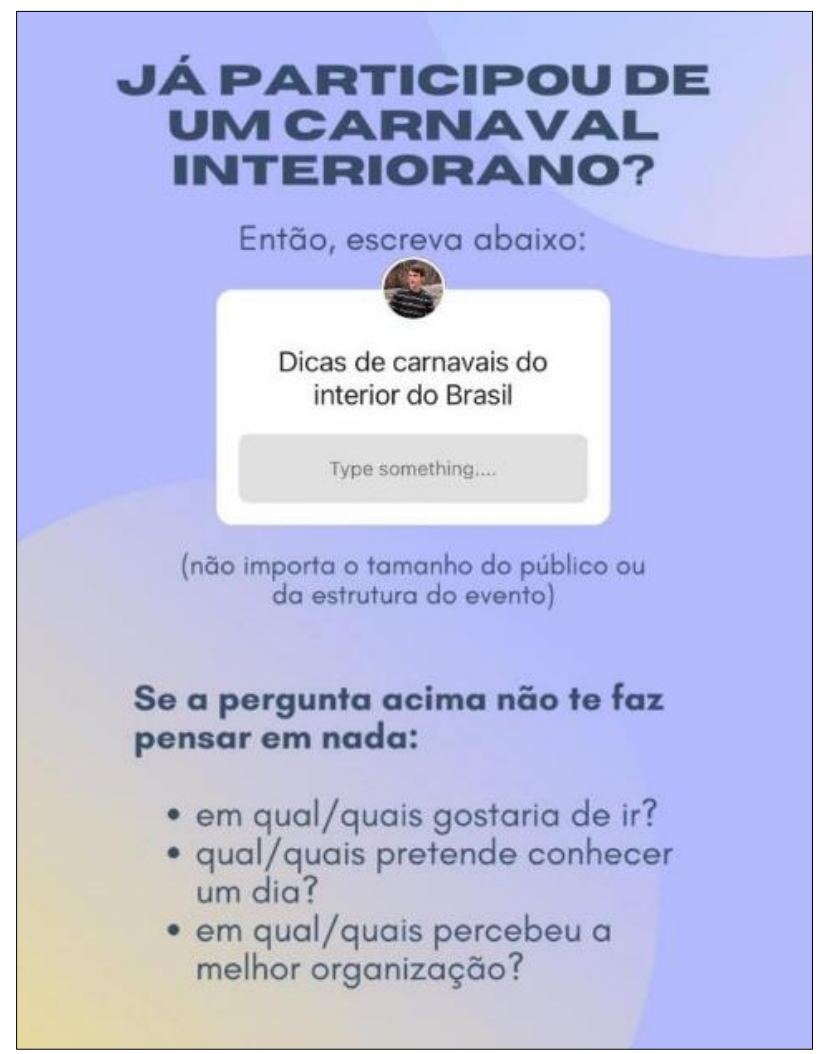

Fonte: Elaborado pelos autores 


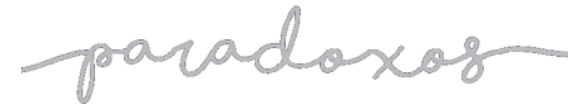

Me dá um dinheiro aí!: Estudo sobre as relações e Intersecções entre publicidade e Criatividade para a sustentabilidade Carnanvalesca interiorana

MOURA, RABAIOLLI, 2021

Figura 2 - Nuvem de palavras com os resultados da pesquisa

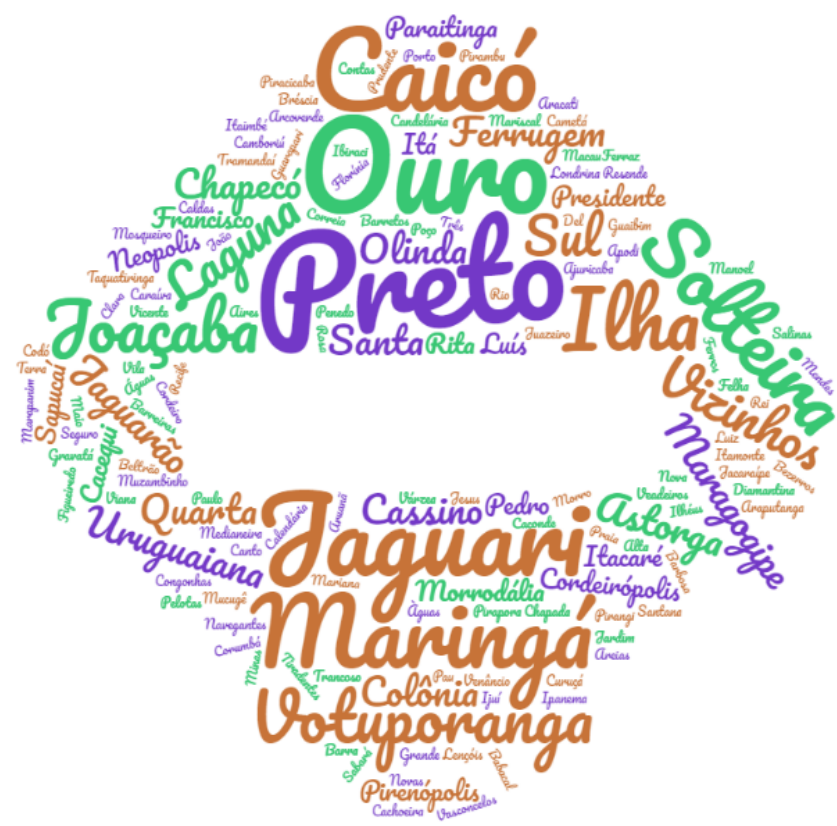

Fonte: Elaborado pelos autores.

Por conseguinte, as análises foram realizadas com os municípios de Corumbá (Goiás), Cametá (Pará), Caicó (Rio Grande do Norte) e Ouro Preto (Minas Gerais). A escolha se deu pela característica dos eventos (público e tipos de carnaval relativos às do município de Rio Pardo) e a relevância do evento na pesquisa e nos resultados de pesquisa da internet.

O carnaval de Corumbá, no interior do Mato Grosso do Sul, é um dos maiores eventos do centro-oeste. A cidade recebe de 20 a 35 mil pessoas por dia de evento. Além disso, em 2020, passou a ser patrimônio imaterial de Mato Grosso do Sul pela Assembleia Legislativa do Mato Grosso do Sul, sendo reconhecida pelos órgãos públicos e pelo estado no Calendário Oficial sul-mato-grossense, assim recebendo, também, mais divulgação em nível nacional.

O município investe cerca de 300 mil reais anualmente em entretenimento, com shows nacionais (como Cláudia Leitte e Grupo Revelação) e locais e possui desfiles de avenida e de blocos oficiais e independentes, Recebe, também, bastante influência carioca em seus laços culturais, contando com a presença de músicos cariocas em seus bastidores, que contribuem para a profissionalização de artistas da região corumbaense. 
Me dá um dinheiro aí!: Estudo sobre as relações e Intersecções entre publicidade e Criatividade para a sustentabilidade Carnanvalesca interiorana

MOURA, RABAIOLLI, 2021

Em 2020, o carnaval corumbaense obteve também o apoio governamental, por meio da Fundação de Cultura, com o recebimento de 700 mil reais, distribuídos entre escolas de samba, blocos e para estrutura da festa. Segundo o Diário Corumbaense (2020), a totalização do investimento chega aos 3,5 milhões de reais. O retorno da aplicação monetária à movimentação da cadeia produtiva é de, mais ou menos, $\mathrm{R} \$ 13$ milhões, fruto do planejamento de uma longa programação e de metodologias como a profissionalização do espetáculo.

A pesquisa revelou que o evento usufrui da criação publicitária para a divulgação de suas atrações e do mapa da cidade durante a festividade, buscando persuadir e gerar interação e compartilhamentos. Em 2018, também foi disponibilizado um documentário sobre o Carnaval da cidade, com o título "Corumbá e o Carnaval de Corumbá", ou seja, investe-se em produtos de mídia, como os visualizados na Figura 3, juntamente com a exemplificação da interação com o veículo e imagens do evento em si.

Figura 3 - Carnaval de Corumbá (Mato Grosso do Sul).

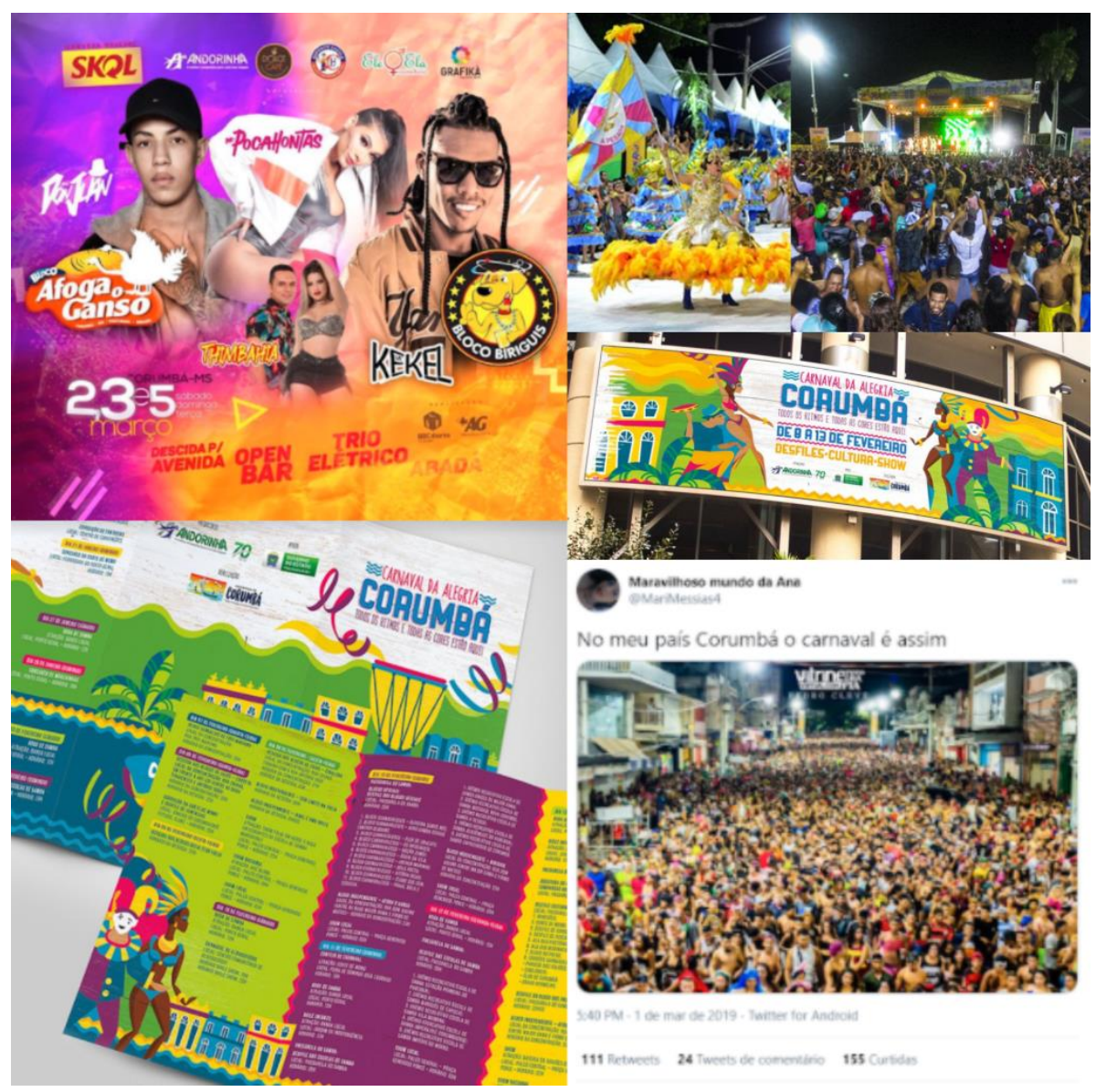

Fonte: Elaborado pelos Autores com dados da pesquisa. 
Além disso, realizam ações e eventos de divulgação, como quando um flashmob foi organizado em uma praça de alimentação da cidade, em 2012. Na ocasião, um músico acomodado comumente começa a reproduzir o samba jingle do carnaval em seu cavaquinho, passando para a entrada de músicos, passistas, dançarinos e personagens típicos da folia corumbaense na performance. A ação de entretenimento de interação com a população presente pôde se converter de sua persuasão à participação na festa e à de outras pessoas, que visualizaram reportagens sobre o ocorrido e se interessaram no evento, compartilhandoo por conta própria, em alguns casos.

Um dos principais diferenciais de Cametá, no interior do Pará, é a sua enorme visibilidade na região norte e em nível nacional. Valendo-se da valorização dos elementos regionais e, consequentemente do entretenimento de seu povo, o espetáculo conta com o "Carnaval das Águas", tradição centenária que cruza os rios da Amazônia e chamou, inclusive, a atenção da Netflix, para o desenvolvimento de uma produção documental que começou a ser desenvolvida em 2020. Trata-se de um produto de entretenimento que, indubitavelmente, irá persuadir os espectadores a conhecê-lo, podendo também gerar o compartilhamento espontâneo pelos admiradores e interessados. No caso do serviço de streaming, é vantajoso pela interação que os habitantes cametaenses podem fazer com a sua marca.

A publicidade, no local, é bastante valorizada, havendo uma preocupação com o fomento das redes sociais e o engajamento do público, sobretudo no período que antecede a realização da festa. O evento investe em grandes atrações para os shows, como as duplas Matheus e Kauan e Maiara e Maraísa e a cantora Gloria Groove.

Entre as ações relevantes realizadas no evento, a Secretaria de Estado de Saúde Pública (Sespa) vinculou-se à festividade, organizando uma campanha de prevenção às infecções sexualmente transmissíveis, oferecendo testes rápidos de HIV e hepatites e distribuindo 1,5 milhão de preservativos entre municípios paraenses, porém principalmente durante os dias de festa em Cametá. (SESPA, 2015). Algumas das informações citadas podem ser visualizadas na Figura 4. 


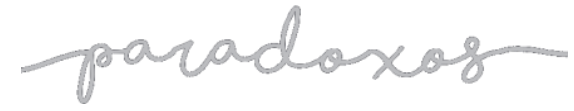

Me dá um dinheiro aí!: Estudo sobre as relações e Intersecções entre publicidade e Criatividade para a sustentabilidade Carnanvalesca interiorana

Figura 4 - Carnaval de Cametá (Pará).

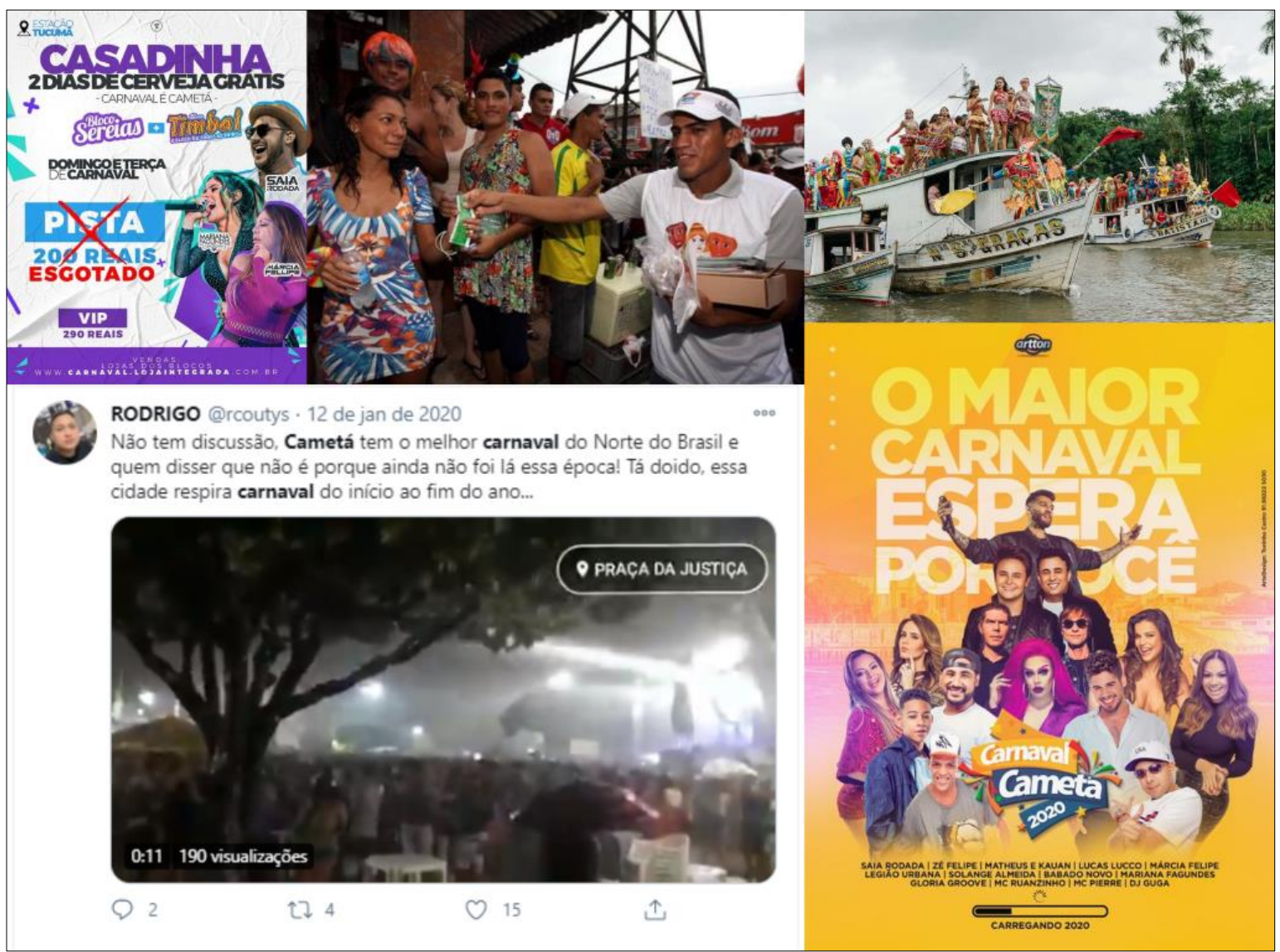

Fonte: Elaborado pelos Autores com dados da pesquisa.

Caicó, município nordestino, localizado no interior do Rio Grande do Norte, tem perfil festivo semelhante às cidades citadas (figura 5). Na interação, participa da folia entre o público com os bonecos de Olinda patrocinado por marcas de lojas da cidade. Seus perfis nas redes sociais são muito atualizados, organizados e com conteúdos planejados que resultam em interação e compartilhamentos, como "dicas de filmes para o fim de semana, com o tema carnavalesco". Para a persuasão, dispõem de diversos produtos, como uma revista especial para o Carnaval de Caicó. 


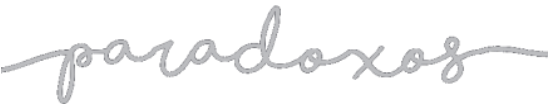

Me dá um dinheiro aí!: Estudo sobre as relações e Intersecções entre publicidade e Criatividade para a sustentabilidade Carnanvalesca interiorana

MOURA, RABAIOLLI, 2021

Figura 5 - Carnaval de Caicó (Rio Grande do Norte).

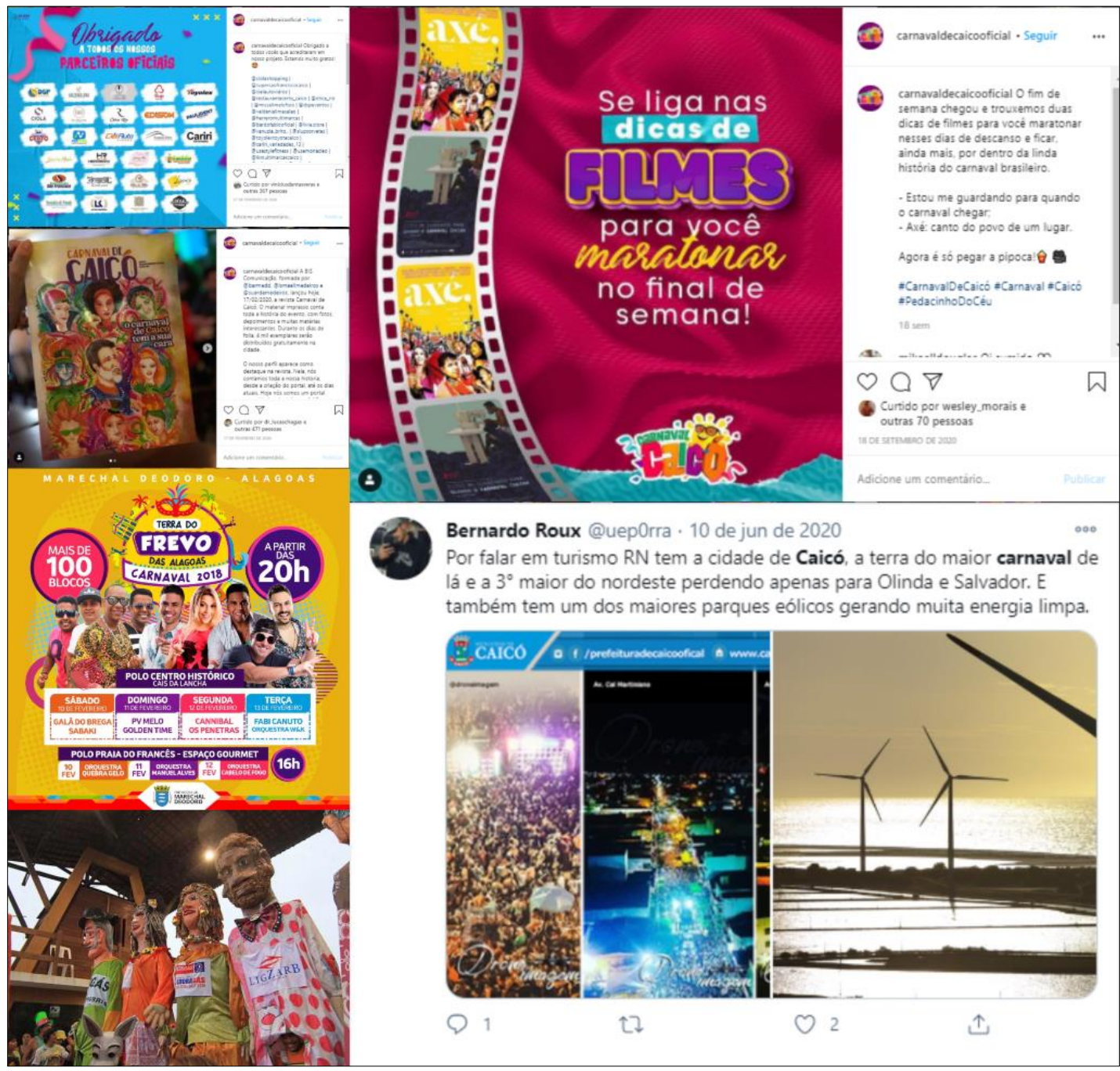

Fonte: Elaborado pelos Autores com dados da pesquisa.

Segundo a Câmera de Dirigentes Logistas (CDL) do município, a festa gira em torno de 60 milhões de reais à economia local. O entretenimento ao turista também é gerado com a aproximação à culinária típica da região, ao artesanato de bordados e ao forró elétrico.

Apesar de ser uma cidade histórica, a cidade do interior do sudeste, Ouro Preto (Minas Gerais) é um dos maiores carnavais universitários do Brasil, com diversas festas temáticas de república e com atrações de interação como o "banho de cerveja", registrado pelos foliões e compartilhados em suas redes sociais. Em 2020, a cidade comemorou 40 anos sendo Patrimônio Cultural da Humanidade pela UNESCO - esse título é um fator relevante para marcas e para a cidade, que contou com investimento de cerca de $\mathrm{R} \$ 2,18$ milhões de reais da Skol e é patrocinadora oficial do evento (com vários guarda-sóis e um palco DOI: http://doi.org/10.14393/par-v6n2-2021-63260 - Paradoxos, Uberlândia, v. 6, n. 2, p. 243-272, jul./dez. 2021 | 263 
Me dá um dinheiro aí!: Estudo sobre as relações e Intersecções entre publicidade e Criatividade para a sustentabilidade Carnanvalesca interiorana

MOURA, RABAIOLLI, 2021

estilizado pela marca. Também possui Bonecos de Olinda com a marca dos anunciantes locais. A figura 6 elucida alguns desses pontos.

Figura 6 - Carnaval de Ouro Preto (Minas Gerais)

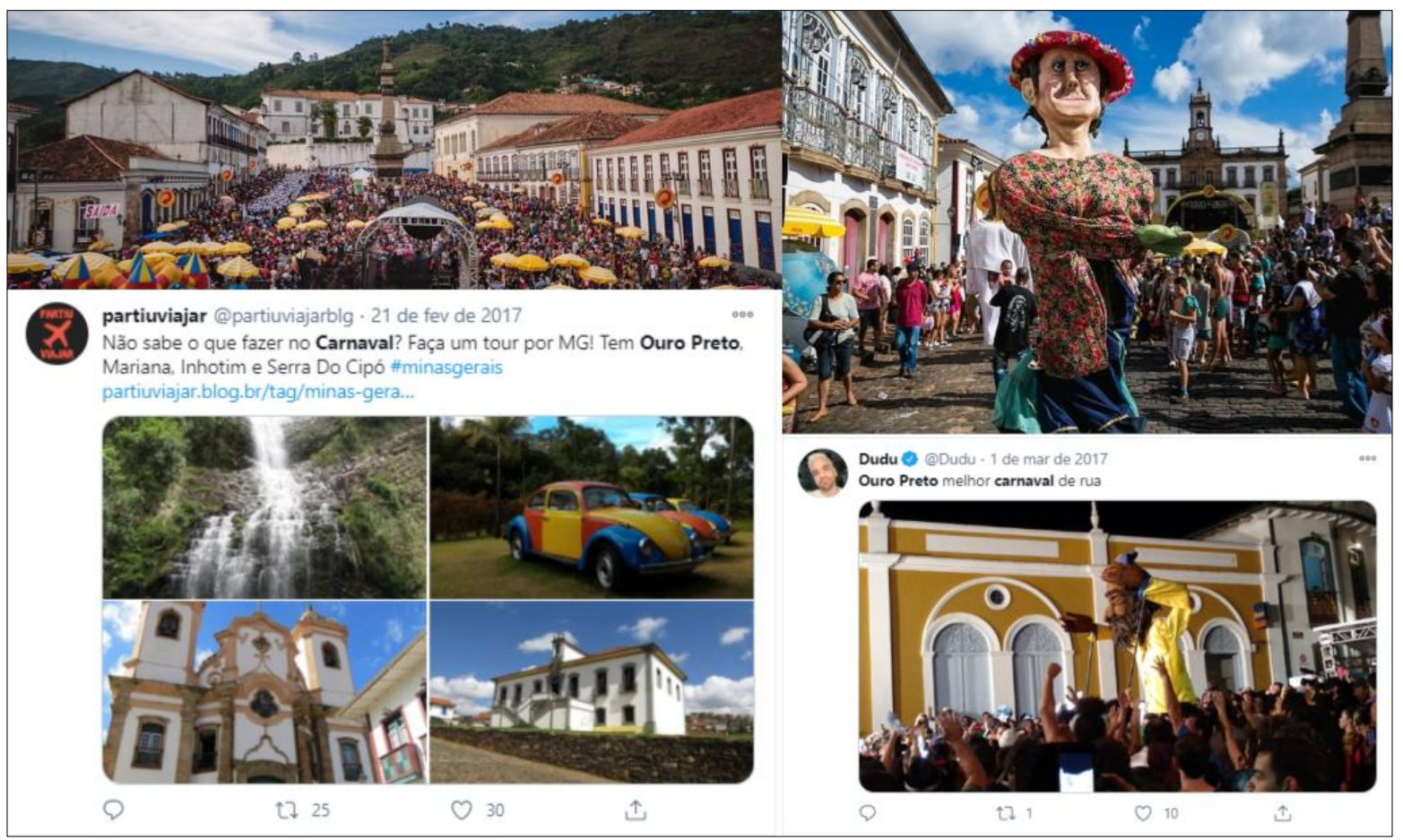

Fonte: Elaborado pelos Autores com dados da pesquisa.

\section{O caso do carnaval de Rio Pardo, Rio Grande do Sul}

Uma análise de cenário sobre o carnaval de Rio Pardo, é feita, a priori, admitindo percepções sobre como a festa é anunciada e comunicada é ausência de um posicionamento definido, assim como o comodismo para a não-execução de uma propaganda que fuja do que já tenha sido realizado.

À fins de contextualização, as origens da celebração carnavalesca da cidade de Rio Pardo, no Rio Grande do Sul, remontam o final do século XIX e primeira metade do século $\mathrm{XX}$, com blocos e agremiações, também conhecidas como cordões, rivais batizados de "Tem Gente Ahi" e "Olha o Grupo", que já desfilavam em meados de 1920. Desses conjuntos de pessoas, foram sendo desenvolvidas algumas das primeiras escolas de samba da região 


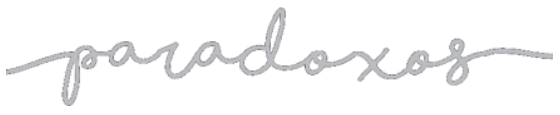

Me dá um dinheiro aí!:

Estudo sobre as relações e Intersecções entre publicidade e Criatividade para a sustentabilidade Carnanvalesca interiorana

MOURA, RABAIOLLI, 2021

central do Rio Grande do Sul, na década de 1950, que percorriam as ruas, mesmo sem a organização que se conhece atualmente (VOGT; ROMERO, 2010).

Em 1959, a primeira escola de samba foi oficialmente fundada. A Candangos, ainda em atividade, era formada principalmente por integrantes da classe média. Já em 1968, integrada por moradores dos bairros, originou-se a Embaixadores do Ritmo, assim como a rivalidade entre os grupos. O Clube Literário e Recreativo, salão localizado no centro da cidade, foi o ponto principal do Carnaval de uma parte da população, marcado por festas luxuosas e alegres, que iam até o amanhecer e, muitas vezes, tinham que ser interrompidas para finalmente serem encerradas. Os "assaltos" às fazendas, dinâmicas que antecediam o Carnaval, uniam os jovens, que eram recebidos com bebidas, salgados e doces caseiros por fazendeiros, em um clima alegre, que garantia o sucesso da festa, ano após ano, desde o fim do ano antecessor, mais precisamente após a escolha da Rainha da edição (VOGT; ROMERO, 2010).

Os tempos são outros, mas o Carnaval continua mobilizando a cidade inteira: com população em 38.968 habitantes, segundo o IBGE (2020), o município atraiu cerca de 120 mil pessoas em 2020 para a Avenida Gogóia, nome dado em homenagem a uma tradicional carnavalesca da cidade à rua Andrade Neves no período da festa, em um dos mais tradicionais desfiles de carnaval do interior do estado, que mobiliza muitas pessoas para seu preparo e registro.

As escolas de samba, com seus temas e enredos, proporcionam a inclusão social e cultural à comunidade. Os foliões também aproveitam os diversos blocos carnavalescos, em desfiles ou em concentrações, enfeitando o centro histórico lusoaçoriano rio-pardense com seus abadás. Profissionais como cantores, compositores, artistas e percussionistas contribuem para a folia, transmitindo e perpetuando seus conhecimentos e vivências para a comunidade.

Em 2020, o júri das Escolas de Samba foi formado por cinco especialistas da Associação de Jurados de Carnaval e Eventos Populares do Rio Grande do Sul (Ajucepergs), a banda Fandangaço movimentou as quatro noites de carnaval, após os desfiles e um camarote esteve instalado ao lado do palco, em frente ao prédio da Prefeitura. As rádios Rio Pardo, da Gazeta Grupo de Comunicações, e Mais FM cobriram o espetáculo em seus respectivos veículos. 


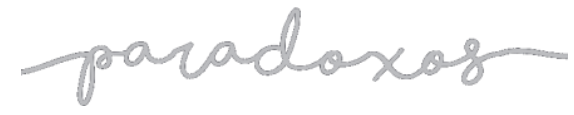

Me dá um dinheiro aí!: Estudo sobre as relações e Intersecções entre publicidade e Criatividade para a sustentabilidade Carnanvalesca interiorana

MOURA, RABAIOLLI, 2021

A divulgação da folia rio-pardense começa apenas nas proximidades do carnaval, isto é, em meados dos meses de janeiro e durante o mês de fevereiro. Durante o restante do ano, são poucas as menções e praticamente nulas as iniciativas que envolvam a festividade, com exceção das iniciativas das Escolas de Samba. De forma independente, esses grupos organizam rodas de samba e venda de pratos em ocasiões especiais, com o objetivo de arrecadarem fundos para a execução dos desfiles alegóricos, anualmente.

O envolvimento da mídia massiva é o maior percebido no município. A emissora filial da Rede Globo, a RBS TV, as rádios Rio Pardo, Mais FM e os jornais Gazeta do Sul e Jornal de Rio Pardo, realizam reportagens e entrevistas para cobrir a preparação final da celebração. Voltadas à comunicação dentro da cidade, carros de som divulgam o evento pelas ruas e uniformes são desenhados para a equipe de trabalho e de apoio carnavalesco. A vestimenta também conta com a montagem da marca anual para o carnaval, uma das expressões de comunicação percebidas, que é aplicada em folders, convites formais e crachás.

Deduz-se que não haja interesse, por parte dos poderes públicos, de realizar-se uma divulgação mais ampla do evento, expressivo por natureza (expressivo por natureza, com desfiles, atrações de rua e opções em salões, demonstrados na figura 7, em uma mesma rua). A propaganda limita-se às artes visualizadas também visualizadas na imagem abaixo, pela possível crença de que ela já esteja presente no inconsciente da população (conforme representado no tuíte) e, por esse motivo, acredita-se que publicidade de forma espontânea e em sua forma tradicional, "boca a boca", pelos habitantes. 


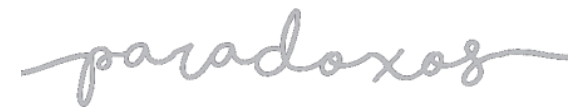

Me dá um dinheiro aí!: Estudo sobre as relações e Intersecções entre publicidade e Criatividade para a sustentabilidade Carnanvalesca interiorana

Figura 7 - Rio Pardo: muita expressividade e pouca amplitude.

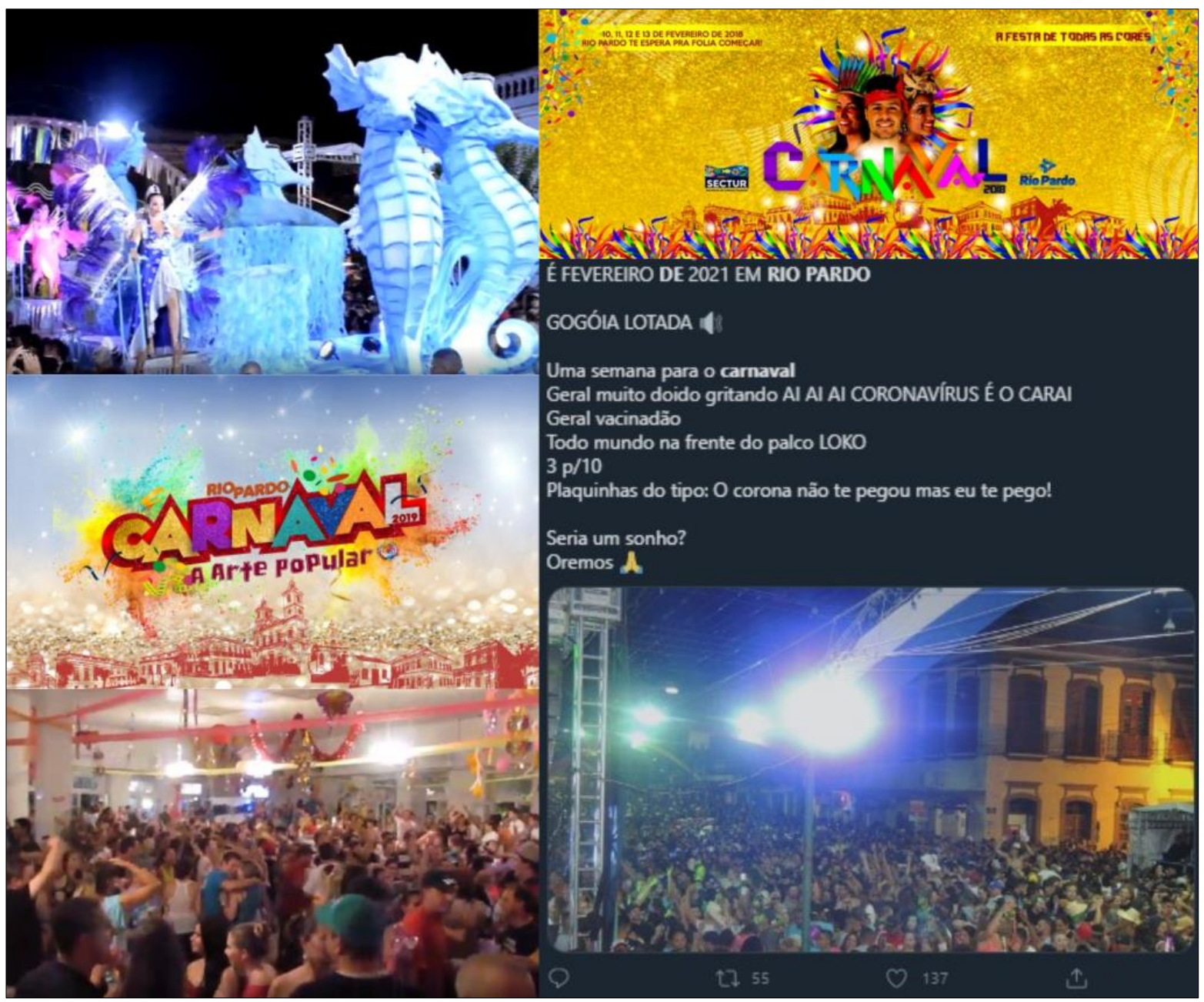

Fonte: Elaborado pelos Autores com dados da pesquisa.

Esses argumentos não são errôneos: a festa faz parte da realidade rio-pardense há décadas e a população, de fato, contribui para a recepção de turistas, em todos os anos, por meio de convites. No entanto, a falta de investimento em comunicação significa insuficientes esforços para o impulsionamento do evento e uma consequente amplitude de alcance e lucros para a receita da cidade. Ademais, o quadro 1 mostra que a relação das marcas apoiadoras do evento, apesar de importante, ainda é pouco explorada e, com uma visão comercial melhor desenvolvida, poderiam qualificar a realização do evento e o retorno de investimento. 
Quadro 1 - Relação de apoiadores e participação no Carnaval de Rio Pardo.

\begin{tabular}{|l|l|}
\hline Nome & Participação \\
\hline CORSAN & $\begin{array}{l}\text { Incentiva O Carnaval de Rua com } \\
\text { recursos para o Desfile na Avenida do } \\
\text { samba Maria da Glória anualmente. }\end{array}$ \\
\hline UNISC & $\begin{array}{l}\text { Pesquisa do PPGE - Mestrado e } \\
\text { Doutorado sobre a Culturalidade e } \\
\text { vivencias educativas dos Povos } \\
\text { Tradicionais }\end{array}$ \\
\hline
\end{tabular}

Fonte: Bittencourt (2020)

Esse comodismo não parece uma ameaça, por enquanto, pois a festividade faz parte de uma escassa quantidade de carnavais na região - e, por esse motivo, poderia agregar-se a esses municípios e desenvolver uma comunicação regionalizada. No entanto, com o anúncio da realização do carnaval na cidade vizinha e polo industrial da região, Santa Cruz do Sul, nos próximos anos, é de se esperar que essa segurança seja estremecida. Grande parte dos turistas do carnaval rio-pardense vêm dessa cidade, ou seja, é eminente a diminuição do público no evento e a precarização da festa em questões estruturais e organizacionais.

A transformação causada pelas cotas de publicidade disponibilizadas nos espaços da avenida do Carnaval de São Paulo, na década de 80 é apenas um dos exemplos da proporção de oportunidades para a contratação de profissionais e a consequente ampliação de possibilidades que pode ocorrer, o que resultou na consagração do evento paulistano no país e sua atual grandiosidade. Também há de se ratificar as iniciativas populares porto-alegrenses, que despertaram o interesse público para a captação de vieses de apoio e patrocínios, na retomada de um evento que, por algum tempo, havia perdido parte de seu fôlego.

Além disso, o que se admite com o que é divulgado e como a comunicação poderia ser aprimorada, em relação aos materiais e inspirações interioranas coletadas com a pesquisa exibida anteriormente, é a consideração do espaço como uma plataforma social e de expressões que acaba sendo um veículo de comunicação, apropriando-se de sua cultura e incentivando o esforço dos agentes, sobretudo os da Indústria Criativa, como os integrantes de entidades carnavalescas, que o fazem acontecer. A visão do município sobre a comunicação também é um entrave ao seu desenvolvimento, visto que não se busca realizar investimentos em possibilidades menos convencionais de publicidade, como a mídia alternativa no carnaval de avenida e de rua. De fato, é uma plataforma de muita força, que DOI: http://doi.org/10.14393/par-v6n2-2021-63260 - Paradoxos, Uberlândia, v. 6, n. 2, p. 243-272, jul./dez. 2021 | 268 


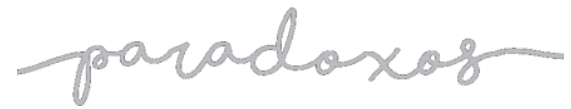

Me dá um dinheiro aí!: Estudo sobre as relações e Intersecções entre publicidade e Criatividade para a sustentabilidade Carnanvalesca interiorana

MOURA, RABAIOLLI, 2021

poderia usufruir de seu ambiente para a realização de ações marcárias, fortalecendo a relação comercial e empresarial da cidade com o poder público e com o setor privado. A Figura 8 demonstra o poder social da festividade, com a elaboração do Bloquinho Ame Juju, ação de solidariedade criada por voluntários do projeto Ame Juju, que buscou arrecadar 9 milhões de reais para a cura da Atrofia Muscular Espinhal (AME), dispondo da avenida carnavalesca como uma das táticas de propagação da mensagem e arrecadação de fundos.

Figura 8 - Bloquinho Ame Juju na avenida.

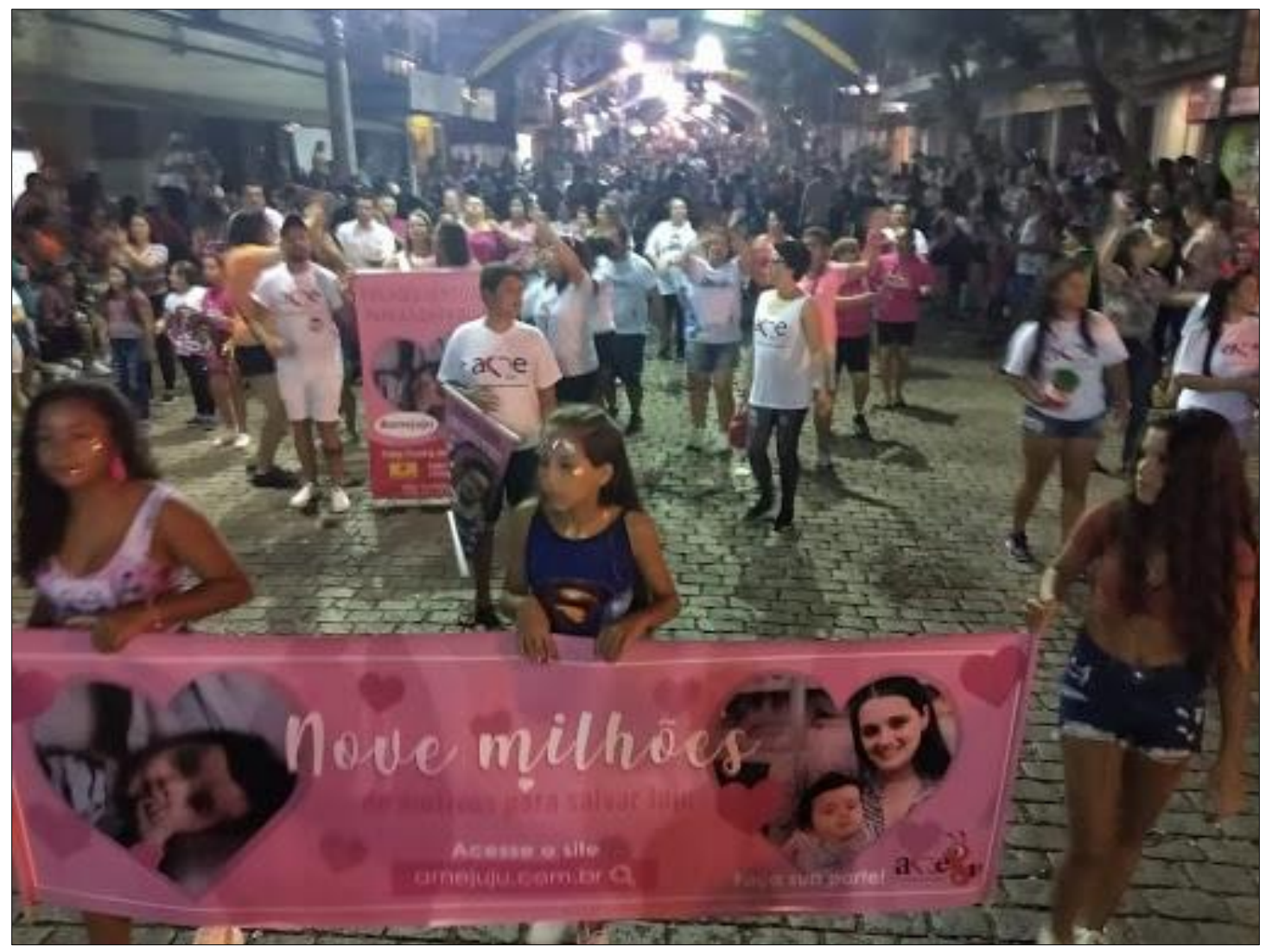

Fonte: Portal GAZ, 2020. ${ }^{2}$

Associando o evento a negócios que buscam persuadir, no cenário carnavalesco, traz possibilidades da geração de identificação e, consequentemente, de influência na

\footnotetext{
${ }^{2}$ Disponível em: http://www.gaz.com.br/conteudos/regional/2020/02/24/162236fotos_bloco_das donzelas_exibe irreverencia no carnaval de rua.html.php. Acesso em 18 fev. 2021.
} 
interação e na intervenção do público quanto às peças e ações visualizadas na rua. Isso também pode gerar compartilhamentos espontâneos pelos foliões, que passam a se tornar disseminadores da publicidade. Sendo assim, a noção de hibridização da publicidade é importante para entender que, atualmente, ela abrange muitos. Tudo isso é importante para movimentar a economia da cidade e, consequentemente gerar melhorias não apenas na cultura, mas em outros setores.

\section{Considerações finais}

Pela revisão bibliográfica, foi possível compreender a grandeza do carnaval e todas as possibilidades que ele permite serem cogitadas, testadas e aplicadas. Entendeuse que as dinâmicas e relações entre os três pilares deste trabalho são aplicáveis à realidade interiorana, em diferentes dimensões.

Em síntese, alguns dos intercâmbios notados foram: 1) $\mathrm{O}$ carnaval relaciona-se à publicidade por também ser uma plataforma social, e mostra-se como um veículo de comunicação por expressar signos e ideias; 2) A hibridização da publicidade contribui para a aplicação de marcas no imaginário e na experiência em torno da ludicidade da folia; 3) A plataforma carnavalesca, pela quantidade de públicos e identidades que contempla, é um veículo muito potente para a mídia; 4) A publicidade cumpre o importante papel de indução ao consumo na Indústria Criativa, onde o Carnaval se insere e, nesse caso, a comunicação que foge aos rígidos moldes estandardizados, tende a obter resultados mais satisfatórios; 5) Apesar do enaltecimento à receita gerada pelo esforço criativo e impostos durante o evento, o que se percebe é um investimento maior na estrutura do que nos agentes que o erguem (músicos, artistas, artesãos, etc.); 6) A inserção da publicidade em espaços e narrativas que não se restringem aos espaços midiáticos sempre constituirá polêmicas, mas há de se exaltar que o investimento publicitário e marcário pode amenizar a falta de recursos públicos e servir como subsídio às festividades.

A midiatização tardia do Carnaval alia-se à uma maior preocupação com profissionalização também tardia. Dessa forma, mesmo que a criatividade seja útil para impulsionar as instituições carnavalescas, isso ainda é feito de forma muito autônoma, com cronogramas intuitivos e processos muito particulares, como a reciclagem de 
fantasias e adereços. As entidades se organizam individualmente durante o ano no fluxo criativo que culmina no desfile de avenida.

Percebe-se que a relação dos carnavais interioranos com a publicidade, que caminha sem rumo, muitas vezes, pela falta de visão estratégica e pelo entendimento das potencialidades desses esforços. Não se exime, também, as responsabilidades dos agentes carnavalescos e da cadeia produtiva do carnaval de resistirem às tentativas de comercialização, negando-se, muitas vezes, a inovação em vez de buscar a convergência entre o que se vê nas ruas e o que é praticado por outros setores - esforços que, muitas vezes, são benéficos a eles.

\section{Referências}

BARONETTI, Bruno S. Da oficialização ao sambódromo: um estudo sobre as escolas de samba de São Paulo (1968-1996). São Paulo, 2014.

BENDASSOLLI, Pedro; WOOD Jr., Thomaz; KIRSCHBAUM, Charles; PINA E CUNHA. Indústrias criativas: definição, limites e possibilidades. RAE - Revista de Administração de Empresas, v. 49, nº 1, jan-mar. 2009, p. 10-18, Fundação Getúlio Vargas Brasil.

BITTENCOURT, Alexandre. 2020. Formulário Edital SEDACTEL no 26/2017: Centenário do Carnaval de Rio Pardo. WhatsApp.

COVALESKI, Rogério. O processo de hibridização da narrativa publicitária. Revista Comunicación, v. 1, no 10, p. 55-62, 2012.

COVALESKI, Rogério. Publicidade híbrida. Curitiba: Maxi, 2010.

DIÁRIO CORUMBAENSE. Uma festa que gera investimento e que foi planejada, define prefeito sobre o carnaval. Leonardo Cabral. Corumbá, 25 fev. 2020. Disponível em: https://diarionline.com.br/?s=noticia\&id=115530. Acesso em: 17 jan. 2021.

FIRJAN. Indústria Criativa: Onde tem Indústria Criativa, tem Firjan. Rio de Janeiro. Disponível em: $\quad$ https://www.firjan.com.br/firjan/empresas/competitividade-empresarial/industriacriativa/default.htm. Acesso em: 25 abr. 2020.

FIRJAN. Mapeamento da Indústria Criativa no Brasil. Rio de Janeiro, 2019. Disponível em: https://www.firjan.com.br/EconomiaCriativa/downloads/MapeamentoIndustriaCriativa.pdf. Acesso em: 25 abr. 2020. 
FIRJAN. Mapeamento da Indústria Criativa no Brasil. Rio de Janeiro, fev. 2019. Disponível em: https://www.firjan.com.br/EconomiaCriativa/downloads/MapeamentoIndustriaCriativa.pdf. Acesso em: 25 abr. 2020.

IBGE. IBGE Cidades: Rio Pardo. Disponível em: https://cidades.ibge.gov.br/brasil/rs/riopardo/panorama. Acesso em: 26 abr. 2020.

LEITÃO, Cláudia Sousa. Políticas Públicas para as Indústrias Criativas. In: GUINDANI, Joel Felipe; SILVA, Marcela Guimarães e. Comunicação e Indústria Criativa: políticas, teorias e estratégias. Jaguarão: Claec, 2018.

LUDERER, Cynthia A. F. O Processo de comunicação na criação do carnavalesco Raul Diniz. São Paulo, 2007.

MANZINI, Eduardo José. Entrevista semi-estruturada: análise de objetivos e de roteiros. In: PRESTES FILHO, Luiz C. Cadeia Produtiva da Economia do Carnaval. Rio de Janeiro: Epapers, 2009.

SESPA distribuirá mais de um milhão de preservativos no carnaval no PA. G1 Pará. 11 fev. 2015. Disponível em: http://g1.globo.com/pa/para/noticia/2015/02/sespa-distribuira-maisde-um-milhao-de-preservativos-no-carnaval-no-pa.html. Acesso em: 18 jan. 2021.

STRANO, Salvador. Marcas e carnaval: o marketing da alegria. Salvador Strano. MEIO \& MENSAGEM., 12 mar. 2019.2 Disponível em: https://www.meioemensagem.com.br/home/marketing/2019/03/01/marcas-e-carnaval-omarketing-da-alegria.html. Acesso em: 25 abr. 2020.

TURETA, César; DE ARAUJO, Bruno F. V. B. Escolas de Samba: trajetória, contradições e contribuições para os estudos organizacionais. Organizações \& Sociedade, v. 20, n. 64, p. 111129, 2013.

VOGT, Paulo Olgário (org.); ROMERO, Maria Rosilane Zoch (org.). RIO PARDO 200 ANOS: uma luz para a história do Rio Grande. 2010. Santa Cruz do Sul: Editora Gazeta Santa Cruz, 2010.

YIN, Robert K. Estudo de caso: planejamento e métodos. 5. ed. Porto Alegre: Bookman, 2015. 